\title{
Molecular Cloning
}

A L A B O RATORY MANUAL

FOURTHEDITION 


\section{OTHER TITLES FROM CSHL PRESS}

\section{LABORATORY MANUALS}

Antibodies: A Laboratory Manual

Imaging: A Laboratory Manual

Live Cell Imaging: A Laboratory Manual, 2nd Edition

Manipulating the Mouse Embryo: A Laboratory Manual, 3rd Edition

RNA: A Laboratory Manual

\section{HANDBOOKS}

Lab Math: A Handbook of Measurements, Calculations, and Other Quantitative Skills for Use at the Bench

Lab Ref, Volume 1: A Handbook of Recipes, Reagents, and Other Reference Tools for Use at the Bench

Lab Ref, Volume 2: A Handbook of Recipes, Reagents, and Other Reference Tools for Use at the Bench

Statistics at the Bench: A Step-by-Step Handbook for Biologists

\section{WEBSITES}

Molecular Cloning, A Laboratory Manual, 4th Edition, www.molecularcloning.org

Cold Spring Harbor Protocols, www.cshprotocols.org 


\section{Molecular Cloning}

\section{A LABORATORY MANUAL}

\section{FOURTHEDITION}

\section{Michael R. Green}

Howard Hughes Medical Institute

Programs in Gene Function and Expression and in Molecular Medicine

University of Massachusetts Medical School

\section{Joseph Sambrook}

Peter MacCallum Cancer Centre and the

Peter MacCallum Department of Oncology

The University of Melbourne, Australia 


\section{Molecular Cloning \\ A LABORATORY MANUAL}

FOURTH EDITION

(C) 2012 by Cold Spring Harbor Laboratory Press, Cold Spring Harbor, New York

All rights reserved

Printed in the United States of America

Publisher

Acquisition Editors

Director of Development, Marketing, \& Sales

Developmental Editors

Project Manager

Permissions Coordinator

Production Editor

Production Manager

Sales Account Manager
John Inglis

John Inglis, Ann Boyle, Alexander Gann

Jan Argentine

Judy Cuddihy, Kaaren Janssen, Michael Zierler

Maryliz Dickerson

Carol Brown

Kathleen Bubbeo

Denise Weiss

Elizabeth Powers

Cover art direction and design: Pete Jeffs, 2012

Library of Congress Cataloging-in-Publication Data

Green, Michael R. (Michael Richard), 1954-

Molecular cloning : a laboratory manual / Michael R. Green,

Joseph Sambrook. - 4th ed.

p. $\mathrm{cm}$.

Rev. ed. of: Molecular cloning : a laboratory manual / Joseph

Sambrook, David W. Russell. 2001.

Includes bibliographical references and index.

ISBN 978-1-936113-41-5 (cloth) - ISBN 978-1-936113-42-2 (pbk.)

1. Molecular cloning-Laboratory manuals. I. Sambrook, Joseph.

II. Sambrook, Joseph. Molecular cloning. III. Title.

QH442.2.S26 2012

$572.8-\mathrm{dc} 23$

2012002613

109887655432

Students and researchers using the procedures in this manual do so at their own risk. Cold Spring Harbor Laboratory makes no representations or warranties with respect to the material set forth in this manual and has no liability in connection with the use of these materials. All registered trademarks, trade names, and brand names mentioned in this book are the property of the respective owners. Readers should please consult individual manufacturers and other resources for current and specific product information.

With the exception of those suppliers listed in the text with their addresses, all suppliers mentioned in this manual can be found on the BioSupplyNet Web site at www.biosupplynet.com.

All World Wide Web addresses are accurate to the best of our knowledge at the time of printing.

Procedures for the humane treatment of animals must be observed at all times. Check with the local animal facility for guidelines.

Certain experimental procedures in this manual may be the subject of national or local legislation or agency restrictions. Users of this manual are responsible for obtaining the relevant permissions, certificates, or licenses in these cases. Neither the authors of this manual nor Cold Spring Harbor Laboratory assume any responsibility for failure of a user to do so.

The materials and methods in this manual may infringe the patent and proprietary rights of other individuals, companies, or organizations. Users of this manual are responsible for obtaining any licenses necessary to use such materials and to practice such methods. COLD SPRING HARBOR LABORATORY MAKES NO WARRANTY OR REPRESENTATION THAT USE OF THE INFORMATION IN THIS MANUAL WILL NOT INFRINGE ANY PATENT OR OTHER PROPRIETARY RIGHT.

Authorization to photocopy items for internal or personal use, or the internal or personal use of specific clients, is granted by Cold Spring Harbor Laboratory Press, provided that the appropriate fee is paid directly to the Copyright Clearance Center (CCC). Write or call CCC at 222 Rosewood Drive, Danvers, MA 01923 (978-750-8400) for information about fees and regulations. Prior to photocopying items for educational classroom use, contact CCC at the above address. Additional information on CCC can be obtained at CCC Online at www. copyright.com.

For a complete catalog of all Cold Spring Harbor Laboratory Press Publications, visit our website at www.cshlpress.org. 


\section{Contents}

List of Tables

XXV

Preface

XXXi

Acknowledgments

xxxiii

\section{VOLUME 1}

\section{PART 1: ESSENTIALS}

\section{CHAPTER 1}

INTRODUCTION

DNA Isolation

Commercial Kits for Purification of DNA

Quantifying DNA

\section{PROTOCOLS}

1 Preparation of Plasmid DNA by Alkaline Lysis with SDS: Minipreps 11

2 Preparation of Plasmid DNA by Alkaline Lysis with SDS: Maxipreps 15

3 Isolating DNA from Gram-Negative Bacteria (e.g., E. coli) 19

4 Precipitation of DNA with Ethanol 21

5 Precipitation of DNA with Isopropanol 26

6 Concentrating and Desalting Nucleic Acids with Microconcentrators 28

7 Concentrating Nucleic Acids by Extraction with Butanol 30

8 Preparation of Single-Stranded Bacteriophage M13 DNA by Precipitation with Polyethylene Glycol

9 Plating Bacteriophage M13

10 Growing Bacteriophage M13 in Liquid Culture 38

11 Preparation of Double-Stranded (Replicative Form) Bacteriophage M13 DNA 41

12 Isolation of High-Molecular-Weight DNA Using Organic Solvents to Purify DNA 44

13 Isolation of High-Molecular-Weight DNA from Mammalian Cells 
14 A Single-Step Method for the Simultaneous Preparation of DNA, RNA, and Protein from Cells and Tissues

15 Preparation of Genomic DNA from Mouse Tails and Other Small Samples

- Alternative Protocol: Isolation of DNA from Mouse Tails without Extraction by Organic Solvents

- Alternative Protocol: One-Tube Isolation of DNA from Mouse Tails

16 Rapid Isolation of Yeast DNA

17 Using Ethidium Bromide to Estimate the Amount of DNA in Bands after Electrophoresis through Minigels

18 Estimating the Concentration of DNA by Fluorometry Using Hoechst $33258 \quad 68$

19 Quantifying DNA in Solution with PicoGreen

\section{INFORMATION PANELS}

DNA Extraction from Formaldehyde-Fixed Tissue Embedded in Paraffin Blocks 72

$\begin{array}{ll}\text { Polyethylene Glycol } & 73\end{array}$

$\begin{array}{ll}\alpha \text {-Complementation } & 74\end{array}$

$\begin{array}{ll}\text { X-Gal } & 76\end{array}$

Minimizing Damage to Large DNA Molecules $\quad 77$

$\begin{array}{lr}\text { Spectrophotometry } & 78\end{array}$

CHAPTER 2

\section{INTRODUCTION}

$\begin{array}{lr}\text { Agarose Gel Electrophoresis } & 82\end{array}$

Analysis of DNA Fragments $\quad 86$

$\begin{array}{lr}\text { Recovering DNA from Gels } & 87\end{array}$

$\begin{array}{lr}\text { Southern Blotting } & 88\end{array}$

\section{PROTOCOLS}

1 Agarose Gel Electrophoresis $\quad 94$

2 Detection of DNA in Agarose Gels by Staining 99

3 Polyacrylamide Gel Electrophoresis 104

4 Detection of DNA in Polyacrylamide Gels by Staining 110

5 Detection of DNA in Polyacrylamide Gels by Autoradiography 112

6 Alkaline Agarose Gel Electrophoresis $\quad 114$

- Additional Protocol: Autoradiography of Alkaline Agarose Gels 117

7 Imaging: Autoradiography and Phosphorimaging 119

8 Recovery of DNA from Agarose Gels Using Glass Beads 125

9 Recovery of DNA from Low-Melting-Temperature $\begin{array}{ll}\text { Agarose Gels: Organic Extraction } & 127\end{array}$

10 Isolation of DNA Fragments from Polyacrylamide Gels by the Crush
and Soak Method

11 Southern Blotting 133

12 Southern Blotting: Simultaneous Transfer of DNA from an Agarose
Gel to Two Membranes 
13 Southern Hybridization of Radiolabeled Probes to Nucleic Acids Immobilized on Membranes

- Additional Protocol: Stripping Probes from Membranes

INFORMATION PANELS

Formamide and Its Uses in Molecular Cloning

\section{CHAPTER 3}

\section{INTRODUCTION}

Plasmid Vectors

Transformation

\section{PROTOCOLS}

1 The Hanahan Method for Preparation and Transformation of Competent E. coli: High-Efficiency Transformation

2 The Inoue Method for Preparation and Transformation of Competent E. coli: "Ultracompetent" Cells

3 Easy Transformation of E. coli: Nanoparticle-Mediated Transformation

- Alternative Protocol: One-Step Preparation of Competent E. coli: Transformation and Storage of Bacterial Cells in the Same Solution

4 Transformation of E. coli by Electroporation

5 Cloning in Plasmid Vectors: Directional Cloning

6 Cloning in Plasmid Vectors: Blunt-End Cloning

7 Dephosphorylation of Plasmid DNA

8 Attaching Phosphorylated Adaptors/Linkers to Blunt-Ended DNAs

9 Cloning PCR Products: Addition of Restriction Sites to the Termini of Amplified DNA

10 Cloning PCR Products: Blunt-End Cloning

\section{INFORMATION PANELS}

Caring for E. coli

$\begin{array}{ll}\text { The History of Transformation of Bacteria by DNA } & 217\end{array}$

A Guide to Cloning the Products of Polymerase Chain Reactions 218

BioBricks and the Ordered Assembly of DNA Fragments 225

TOPO Tools: Creating Linear Expression Constructs with Functional Elements 227

$\begin{array}{lr}\text { Antibiotics } & 229\end{array}$

$\begin{array}{lr}\text { Adaptors } & 232\end{array}$

$\begin{array}{ll}\text { Linkers } & 234\end{array}$

$\begin{array}{lr}\text { Ligation and Ligases } & 235\end{array}$ 
$\begin{array}{lr}\text { Condensing and Crowding Reagents } & 240 \\ \text { The Discovery of Restriction Enzymes } & 241 \\ \text { Restriction Enzymes } & 242 \\ \text { Chloramphenicol } & 245 \\ \text { The } c \text { dB Gene } & 247 \\ \text { Bacteriophage } \lambda & 248 \\ \text { Bacteriophage M13 } & 249 \\ \text { Plasmids } & 251 \\ \text { Cosmids } & 258\end{array}$

\section{CHAPTER 4}

Gateway Recombinational Cloning

John S. Reece-Hoyes and Albertha J.M. Walhout

\section{INTRODUCTION}

Basic Principles and Applications of Gateway Cloning

\section{PROTOCOLS}

1 Propagating Gateway Vectors

2 Generating an ORF Entry Clone and Destination Clone 270

3 Using Multisite LR Cloning to Generate a Destination Clone 277

\section{INFORMATION PANEL}

Generating Gateway-Compatible Vectors

\section{CHAPTER 5}

Working with Bacterial Artificial Chromosomes and Other High-Capacity Vectors

\section{INTRODUCTION}

Development of High-Capacity Vectors: Advantages and Disadvantages 282

Working with Bacterial Artificial Chromosomes

\section{PROTOCOLS}

1 Small-Scale Isolation of BAC DNA and Verification by PCR 294

2 Large-Scale Preparation and Linearization of BAC DNA 297

3 Examination of BAC DNA Quality and Quantity by Pulsed-Field Gel Electrophoresis 301

4 Two-Step BAC Engineering: Preparation of Shuttle Vector DNA 303

5 Preparation of the A Homology Arm (A-Box) and B Homology Arm (B-Box) 306

6 Cloning of the A and B Homology Arms into the Shuttle Vector 309

7 Preparation and Verification of the Recombinant Shuttle Vector 312 
8 Electroporation of Competent BAC Host Cells with the Recombinant Shuttle Vector

9 Verification of Cointegrates and Selection of Resolved BAC Clones

10 One-Step BAC Modification: Preparation of Plasmids

11 Preparation of the A Homology Arm (A-Box)

13 Transformation of the BAC Host with the RecA Vector

14 Transfer of the Reporter Vector into BAC/RecA Cells and Selection of Cointegrates

15 Growth of S. cerevisiae and Preparation of DNA

16 Small-Scale Preparations of Yeast DNA

\section{INFORMATION PANELS}

CRE-IOXP

Using EGFP as a Reporter

Primer Design for Homology Arms, Cointegration, and Resolution

Yeast Media

\section{CHAPTER 6}

\section{INTRODUCTION}

\section{PROTOCOLS}

Introduction to the Isolation of Total RNA Using Monophasic Lysis Reagents

1 Purification of Total RNA from Mammalian Cells and Tissues

- Alternative Protocol: Preparing RNA from Smaller Samples

3 Total RNA Isolation from Drosophila melanogaster

4 Total RNA Extraction from Caenorhabditis elegans

5 Total RNA Extraction from Saccharomyces cerevisiae Using Hot Acid Phenol

6 Quantifying and Storing RNA

7 Precipitation of RNA with Ethanol

8 Removing DNA Contamination from RNA Samples by Treatment with RNase-Free DNase I $\quad 375$

9 Isolation of Poly(A) ${ }^{+}$Messenger RNA Using Magnetic Oligo(dT) Beads 377

Introduction to Hybridization of RNA by Northern Transfer 381

10 Separation of RNA according to Size: Electrophoresis of RNA through Agarose Gels Containing Formaldehyde

11 Separation of RNA according to Size: Electrophoresis of RNA through Denaturing Urea Polyacrylamide Gels

12 Transfer and Fixation of Denatured RNA in Agarose Gels to Membranes 401

- Alternative Protocol: Capillary Transfer by Downward Flow 
13 Transfer and Fixation of Denatured RNA in Polyacrylamide Gels to Membranes by Electrophoretic Transfer

14 Northern Hybridization

15 Dot and Slot Hybridization of Purified RNA 415

Introduction to Mapping RNA $\quad 420$

16 Mapping RNA with Nuclease S1 430

17 Ribonuclease Protection: Mapping RNA with Ribonuclease and Radiolabeled RNA Probes

18 Analysis of RNA by Primer Extension

\section{INFORMATION PANELS}

How to Win the Battle with RNase $\quad 450$

Inhibitors of RNases $\quad 451$

Diethylpyrocarbonate $\quad 452$

$\begin{array}{lr}\text { Nuclease S1 } & 454\end{array}$

\section{CHAPTER 7}

\section{INTRODUCTION}

The Basic Polymerase Chain Reaction $\quad 456$

Design of Oligonucleotide Primers for Basic PCR 462

Detecting, Analyzing, and Quantifying mRNAs 464

Contamination in PCR 466

\section{PROTOCOLS}

1 The Basic Polymerase Chain Reaction $\quad 470$

2 Hot Start PCR 477

3 Touchdown PCR 481

4 PCR Amplification of GC-Rich Templates 484

5 Long and Accurate PCR (LA PCR) 490

6 Inverse PCR 494

7 Nested PCR 499

8 Amplification of cDNA Generated by Reverse Transcription of mRNA: Two-Step
RT-PCR

9 Rapid Amplification of Sequences from the 5' Ends of mRNAs: 5'-RACE 515

10 Rapid Amplification of Sequences from the 3' Ends of mRNAs: 3'-RACE 523

11 Screening Colonies by PCR

\section{INFORMATION PANELS}

Taq DNA Polymerase $\quad 533$

$\begin{array}{ll}\text { PCR in Theory } & 537\end{array}$

Ribonuclease H $\quad 538$

The dut and ung Genes of E. coli $\quad 539$

$\begin{array}{lr}\text { Terminal Transferase } & 540\end{array}$ 


\section{CHAPTER 8}

Jui-Hung Hung and Zhiping Weng

\section{INTRODUCTION}

\section{PROTOCOLS}

1 Visualizing Genomic Annotations with the UCSC Genome Browser 544 Introduction to Sequence Alignment and Homology Search 554

2 Sequence Alignment and Homology Search with BLAST and ClustalW 557

3 Designing PCR Primers Using Primer3Plus 564

Introduction to Expression Profiling by Microarray and RNA-seq 571

4 Expression Profiling by Microarray and RNA-seq $\quad 577$

Introduction to Mapping Billions of Short Reads to a Reference Genome 588

5 Mapping Billions of Short Reads to a Reference Genome $\quad 591$

$\begin{array}{ll}\text { Introduction to Peak-Finding Algorithms } & 598\end{array}$

6 Identifying Regions Enriched in a ChIP-seq Data Set (Peak Finding) 604

Introduction to Motif Finding $\quad 612$

7 Discovering cis-Regulatory Motifs $\quad 617$

INFORMATION PANELS

$\begin{array}{lr}\text { Data Formats } & 625\end{array}$

$\begin{array}{lr}\text { Algorithms, Portals, and Methods } & 628\end{array}$

\section{VOLUME 2}

\section{PART 2: ANALYSIS AND MANIPULATION OF DNA AND RNA}

\section{CHAPTER 9}

\section{INTRODUCTION}

Real-Time PCR Chemistries

Extracting Data from a Real-Time PCR Experiment: Data Analysis and Normalization Methods

Designing Primers and Probes and Optimizing Conditions for Real-Time PCR 643

$\begin{array}{lr}\text { Constructing a Standard Curve } & 648\end{array}$

$\begin{array}{lr}\text { Performing Real-Time PCR } & 650\end{array}$

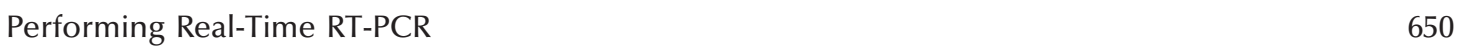

MIQE Guidelines $\quad 654$

Real-Time PCR Protocols $\quad 654$ 


\section{PROTOCOLS}

1 Optimizing Primer and Probe Concentrations for Use in Real-Time PCR 658

2 Constructing a Standard Curve $\quad 663$

3 Quantification of DNA by Real-Time PCR 667

4 Quantification of RNA by Real-Time RT-PCR 670

5 Analysis and Normalization of Real-Time PCR Experimental Data 674

\section{INFORMATION PANELS}

$\begin{array}{lr}\text { Multiplex PCR } & 680\end{array}$

$\begin{array}{ll}\text { SNP Genotyping } & 681\end{array}$

\section{CHAPTER 10}

\section{INTRODUCTION}

Microarray Applications $\quad 685$

$\begin{array}{lr}\text { Performing Microarray Experiments } & 688\end{array}$

\section{PROTOCOLS}

1 Printing Microarrays $\quad 694$

2 Round A/Round B Amplification of DNA $\quad 698$

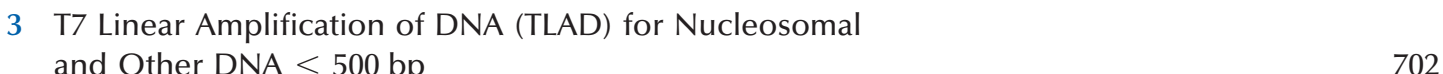

4 Amplification of RNA $\quad 709$

5 Direct Cyanine-dUTP Labeling of RNA $\quad 715$

6 Indirect Aminoallyl-dUTP Labeling of RNA $\quad 718$

7 Cyanine-dCTP Labeling of DNA Using Klenow $\quad 721$

8 Indirect Labeling of DNA $\quad 724$

9 Blocking Polylysines on Homemade Microarrays $\quad 726$

10 Hybridization to Homemade Microarrays $\quad 729$

\section{CHAPTER 11}

Elaine Mardis and W. Richard McCombie

\section{INTRODUCTION}

History of Sanger/Dideoxy DNA Sequencing $\quad 736$

$\begin{array}{ll}\text { Next-Generation Sequencing } & 742\end{array}$

Overview of Next-Generation Sequencing Instruments $\quad 752$

Sanger Sequencing versus Next-Generation Sequencing: When to Do What? 760

$\begin{array}{ll}\text { Introduction to Protocols } & 761\end{array}$ 
SECTION I. LIBRARY PREPARATIONS FOR VARIOUS PLATFORMS

Capillary Sequencing

1 Preparing Plasmid Subclones for Capillary Sequencing 764

2 Preparing PCR Products for Capillary Sequencing $\quad 770$

3 Cycling Sequencing Reactions $\quad 773$

Illumina

4 Whole Genome: Manual Library Preparation $\quad 776$

5 Whole Genome: Automated, Nonindexed Library Preparation $\quad 783$

- Additional Protocol: Automated Library Preparation 789

6 Whole Genome: Automated, Indexed Library Preparation $\quad 792$

7 Preparation of a 3-kb Mate-Pair Library for Illumina Sequencing 799

8 Preparation of an 8-kb Mate-Pair Library for Illumina Sequencing 808

- Additional Protocol: AMPure Bead Calibration 821

9 RNA-Seq: RNA Conversion to cDNA and Amplification $\quad 824$

- Additional Protocol: RNAClean XP Bead Cleanup (before RNA-Seq) 830

10 Solution-Phase Exome Capture $\quad 831$

- Additional Protocol: AMPure XP Bead Cleanup 840

- Additional Protocol: Agarose Gel Size Selection 842

11 Automated Size Selection $\quad 844$

12 Library Quantification Using SYBR Green-qPCR 848

13 Library Quantification Using PicoGreen Fluorometry 852

14 Library Quantification: Fluorometric Quantitation of Double-Stranded or Single-Stranded DNA Samples Using the Qubit System $\quad 857$

Pyrosequencing

15 Preparation of Small-Fragment Libraries for 454 Sequencing 859

16 sstDNA Library Capture and emPCR 866

17 Roche/454 Sequencer: Executing a Sequencing Run 874

SECTION II. POSTSEQUENCING ANALYSES

18 Validation $\quad 883$

19 Quality Assessment of Sequence Data $\quad 885$

20 Data Analysis $\quad 887$

INFORMATION PANELS

$\begin{array}{lr}\text { Biotin } & 888\end{array}$

$\begin{array}{lr}\text { Magnetic Beads } & 890\end{array}$

$\begin{array}{lr}\text { Fragmenting of DNA } & 892\end{array}$

\section{CHAPTER 12}

Analysis of DNA Methylation in Mammalian Cells 893

Paul M. Lizardi, Qin Yan, and Narendra Wajapeyee

\section{INTRODUCTION}

DNA Methylation Affects and Reveals Biological Phenomena 894

Experimental Approaches for Analysis of DNA Methylation 895 


\section{PROTOCOLS}

1 DNA Bisulfite Sequencing for Single-Nucleotide-Resolution DNA Methylation Detection

2 Methylation-Specific PCR for Gene-Specific DNA Methylation Detection 907

3 Methyl-Cytosine-Based Immunoprecipitation for DNA Methylation Analysis 911

4 High-Throughput Deep Sequencing for Mapping Mammalian DNA Methylation 915

5 Roche 454 Clonal Sequencing of Bisulfite-Converted DNA Libraries 927

6 Illumina Sequencing of Bisulfite-Converted DNA Libraries 932

\section{INFORMATION PANELS}

Public Domain Software for Identifying CpG Islands in Promoter and Coding Regions of Mammalian Genes

Designing Primers for the Amplification of Bisulfite-Converted Product to Perform

\section{CHAPTER 13}

\section{INTRODUCTION}

Radioactive versus Nonradioactive Labeling of Nucleic Acids $\quad 944$

Types of Nonradioactive Detection Systems 948

Designing Oligonucleotides for Use as Probes 953

\section{PROTOCOLS}

1 Random Priming: Labeling of Purified DNA Fragments by Extension of Random Oligonucleotides

2 Random Priming: Labeling of DNA by Extension of Random Oligonucleotides in the Presence of Melted Agarose

3 Labeling of DNA Probes by Nick Translation 974

4 Labeling of DNA Probes by Polymerase Chain Reaction 978

- Additional Protocol: Asymmetric Probes 982

5 Synthesis of Single-Stranded RNA Probes by In Vitro Transcription 984

- Additional Protocol: Using PCR to Add Promoters for Bacteriophage-Encoded RNA Polymerases to Fragments of DNA

6 Synthesis of cDNA Probes from mRNA Using Random Oligonucleotide Primers 994

7 Radiolabeling of Subtracted cDNA Probes by Random Oligonucleotide Extension

8 Labeling 3' Termini of Double-Stranded DNA Using the Klenow Fragment of E. coli DNA Polymerase I

9 Dephosphorylation of DNA Fragments with Alkaline Phosphatase 1009

10 Phosphorylation of DNA Molecules with Protruding 5'-Hydroxyl Termini 
11 Phosphorylation of DNA Molecules with Dephosphorylated Blunt Ends or Recessed 5' Termini

13 Labeling the $3^{\prime}$ Termini of Oligonucleotides Using Terminal Deoxynucleotidyl Transferase

- Alternative Protocol: Synthesizing Nonradiolabeled Probes Using TdT

- Additional Protocol: Tailing Reaction

- Additional Protocol: Modifications for Synthesizing Nonradiolabeled Probes

14 Labeling of Synthetic Oligonucleotides Using the Klenow Fragment of E. coli DNA Polymerase I

16 Purification of Labeled Oligonucleotides by Size-Exclusion Chromatography

18 Hybridization of Oligonucleotide Probes in Aqueous Solutions: Washing in Buffers Containing Quaternary Ammonium Salts

\section{INFORMATION PANELS}

Preparation of Stock Solutions of dNTPS

\section{CHAPTER 14}

\section{INTRODUCTION}

Mutagenesis Approaches $\quad 1064$

Research Goals 1065

$\begin{array}{ll}\text { Commercial Kits } & 1065\end{array}$

\section{PROTOCOLS}

1 Random Mutagenesis Using Error-Prone DNA Polymerases 1068

2 Creating Insertions or Deletions Using Overlap Extension PCR Mutagenesis 1080

3 In Vitro Mutagenesis Using Double-Stranded DNA Templates: Selection of Mutants with Dpnl 1087

4 Altered $\beta$-Lactamase Selection Approach for Site-Directed Mutagenesis 1095

5 Oligonucleotide-Directed Mutagenesis by Elimination of a Unique Restriction Site (USE Mutagenesis)

6 Saturation Mutagenesis by Codon Cassette Insertion 1108

7 Random Scanning Mutagenesis 1115

8 Multisite-Directed Mutagenesis 1120

9 Megaprimer PCR-Based Mutagenesis 1124 


\section{INFORMATION PANELS}

$\begin{array}{ll}\text { Domain Mutagenesis } & 1127\end{array}$

$\begin{array}{lr}\text { High-Throughput Site-Directed Mutagenesis of Plasmid DNA } & 1128\end{array}$

$N^{6}$-Methyladenine, Dam Methylase, and Methylation-Sensitive

Restriction Enzymes

\section{PART 3: INTRODUCING GENES INTO CELLS}

\section{CHAPTER 15}

Priti Kumar, Arvindhan Nagarajan, and Pradeep D. Uchil

\section{INTRODUCTION}

Transient Versus Stable Transfection 1133

Transfection Methods 1133

$\begin{array}{lr}\text { Transfection Controls } & 1133\end{array}$

$\begin{array}{ll}\text { Optimization and Special Considerations } & 1136\end{array}$

$\begin{array}{ll}\text { Assessing Cell Viability in Transfected Cell Lines } & 1137\end{array}$

\section{PROTOCOLS}

1 DNA Transfection Mediated by Cationic Lipid Reagents 1139

- Alternative Protocol: Transfection Using DOTMA and DOGS 1145

- Additional Protocol: Histochemical Staining of Cell Monolayers for $\beta$-Galactosidase 1148

2 Calcium-Phosphate-Mediated Transfection of Eukaryotic Cells with Plasmid DNAs

- Alternative Protocol: High-Efficiency Calcium-Phosphate-Mediated Transfection of Eukaryotic Cells with Plasmid DNAs

3 Calcium-Phosphate-Mediated Transfection of Cells with High-Molecular-Weight Genomic DNA

- Alternative Protocol: Calcium-Phosphate-Mediated Transfection of Adherent Cells

- Alternative Protocol: Calcium-Phosphate-Mediated Transfection of Cells Growing in Suspension

4 Transfection Mediated by DEAE-Dextran: High-Efficiency Method

- Alternative Protocol: Transfection Mediated by DEAE-Dextran: Increased Cell Viability

5 DNA Transfection by Electroporation 1173

6 Analysis of Cell Viability by the alamarBlue Assay 1177

7 Analysis of Cell Viability by the Lactate Dehydrogenase Assay 1180

8 Analysis of Cell Viability by the MTT Assay 1183

\section{INFORMATION PANELS}

Optical Transfection 1186

$\begin{array}{lr}\text { Cotransformation } & 1188\end{array}$

Selective Agents for Stable Transformation 1190

$\begin{array}{lr}\text { Lipofection } & 1194\end{array}$ 


\section{CHAPTER 16}

\section{INTRODUCTION}

Factors to Consider When Choosing a Viral Vector

The Major Types of Viruses Currently Used as Vectors

Adenovirus Vectors

Adeno-Associated Virus Vectors

\section{PROTOCOLS}

1 Construction of Recombinant Adenovirus Genomes by Direct Cloning

2 Release of the Cloned Recombinant Adenovirus Genome for Rescue and Expansion

3 Purification of the Recombinant Adenovirus by Cesium Chloride Gradient Centrifugation

4 Characterization of the Purified Recombinant Adenovirus Vector for Viral Genome Structure by Restriction Enzyme Digestions

5 Measuring the Infectious Titer of Recombinant Adenovirus Vectors Using $\mathrm{TCID}_{50}$ End-Point Dilution and qPCR

- Additional Protocol: Preparation of a DNA Standard for qPCR

6 Detection Assay for Replication-Competent Adenovirus by Concentration Passage and Real-Time qPCR

7 Production of rAAVs by Transient Transfection

8 Purification of rAAVs by Cesium Chloride Gradient Sedimentation

9 Purification of rAAVs by lodixanol Gradient Centrifugation

10 Purification of rAAV2s by Heparin Column Affinity Chromatography

11 Enrichment of Fully Packaged Virions in Column-Purified rAAV Preparations by lodixanol Gradient Centrifugation Followed by Anion-Exchange Column Chromatography

13 Sensitive Determination of Infectious Titer of rAAVs Using TCID 50 End-Point Dilution and qPCR

14 Analysis of rAAV Sample Morphology Using Negative Staining and High-Resolution Electron Microscopy 
xviii / Contents

17 Titration of Lentivirus Vectors

18 Monitoring Lentivirus Vector Stocks for Replication-Competent Viruses

INFORMATION PANELS

Adenovirus Vectors

AAV Vectors

Lentivirus Vectors

Basic Elements in Viral Vectors

VOLUME 3

\section{PART 4: GENE EXPRESSION}

\section{CHAPTER 17}

Analysis of Gene Regulation Using Reporter Systems

Pradeep D. Uchil, Arvindhan Nagarajan, and Priti Kumar

\section{INTRODUCTION}

Introduction to Reporter Systems

Reporter Genes Used in the Analysis of Regulatory Elements

Assaying for $\beta$-Galactosidase in Extracts of Mammalian Cells

\section{PROTOCOLS}

1 Assay for $\beta$-Galactosidase in Extracts of Mammalian Cells 1346

- Additional Protocol: Chemiluminescent Assay for $\beta$-Galactosidase Activity 1350

2 Single Luciferase Reporter Assay 1354

3 Dual Luciferase Reporter Assay 1359

4 Using ELISA to Measure GFP Production 1366

5 Generation of Cell Lines with Tetracycline-Regulated Gene Expression 1370

- Additional Protocol: Selecting Stable Clones via Limiting Dilution
of Suspension Cells

\section{INFORMATION PANELS}

$\begin{array}{ll}\text { Fluorescent Proteins } & 1381\end{array}$

Epitope Tagging 1394

$\begin{array}{ll}\beta \text {-Galactosidase } & 1401\end{array}$

$\begin{array}{ll}\text { Luciferase } & 1406\end{array}$

$\begin{array}{lr}\text { Tetracycline } & 1409\end{array}$ 


\section{CHAPTER 18}

\section{INTRODUCTION}

Reverse Genetics by RNAi

\section{PROTOCOLS}

1 Preparation of siRNA Duplexes

2 RNAi in Mammalian Cells by siRNA Duplex Transfection

3 RNAi in Drosophila S2 Cells by siRNA Duplex Transfection

4 Preparation of dsRNAs by In Vitro Transcription

5 RNAi in Drosophila S2 Cells by dsRNA Soaking

6 RNAi in Drosophila S2 Cells by dsRNA Transfection

7 Analysis of Small RNAs by Northern Hybridization

8 Analysis of Small RNAs by Quantitative Reverse Transcription PCR 1453

9 Construction of Small RNA Libraries for High-Throughput Sequencing 1456

10 Preparation of Antisense Oligonucleotides to Inhibit miRNA Function 1466

11 Inhibiting miRNA Function by Antisense Oligonucleotides in Cultured Mammalian Cells

\section{INFORMATION PANEL}

Genome-Wide RNA Interference: Functional Genomics in the Postgenomics Era

\section{CHAPTER 19}

Clara L. Kielkopf, William Bauer, and Ina L. Urbatsch

\section{INTRODUCTION}

Choosing an Expression System 1483

$\begin{array}{lr}\text { Choosing an Appropriate Expression Vector } & 1488\end{array}$

Fusion Proteins 1499

Optimization of Expression of Foreign Proteins 1503

\section{PROTOCOLS}

1 Expression of Cloned Genes in E. coli Using IPTG-Inducible Promoters 1508

- Additional Protocol: Small-Scale Test for Soluble Target Protein Expression 1514

- Alternative Protocol: Expression of Cloned Genes in E. coli Using the Arabinose $B A D$ Promoter

- Alternative Protocol: Subcellular Localization of Signal Peptide Fusion Proteins 
2 Expression of Cloned Genes Using the Baculovirus Expression System

- Additional Protocol: Plaque Assay to Determine the Titer of the Baculovirus Stock

- Alternative Protocol: Production of Bacmid DNA for Transfection into Insect Cells

3 Expression of Cloned Genes in P. pastoris Using the Methanol-Inducible Promoter AOX1

- Additional Protocol: Cryostorage of Yeast Cultures

4 Preparation of Cell Extract for Purification of Soluble Proteins Expressed in E. coli

- Additional Protocol: Lysis of Yeast Cells Using Glass Beads

- Alternative Protocol: Preparation of E. coli Cell Extract Using Gentle, Heat-Induced Enzymatic Lysis

- Alternative Protocol: Preparation of E. coli Cell Extract Using Freeze-Thaw with Enzymatic Lysis by Lysozyme

5 Purification of Polyhistidine-Tagged Proteins by Immobilized Metal Affinity Chromatography

- Additional Protocol: Regenerating and Cleaning the $\mathrm{Ni}^{2+}-\mathrm{NTA}$ Resin

- Alternative Protocol: Fast Performance Liquid Chromatography Purification of Histidine-Tagged Proteins

6 Purification of Fusion Proteins by Affinity Chromatography on Glutathione Resin 1586

7 Solubilization of Expressed Proteins from Inclusion Bodies 1593

8 SDS-PAGE of Proteins

- Alternative Protocol: Variations of Staining SDS-Polyacrylamide Gels with Coomassie Brilliant Blue

- Alternative Protocol: Staining SDS-Polyacrylamide Gels with Silver Salts 1611

9 Analysis of Proteins by Immunoblotting 1616

10 Methods for Measuring the Concentrations of Proteins 1625

\section{INFORMATION PANELS}

Considerations for Membrane Protein Purification 1632

Historical Footnote: Coomassie Brilliant Blue 1636

\section{PART 5: INTERACTION ANALYSIS}

\section{CHAPTER 20}

\section{INTRODUCTION}

Formaldehyde Cross-Linking to Interrogate Genomic Interactions 1638

$\begin{array}{ll}\text { ChIP Analysis of Protein-DNA Interactions } & 1638\end{array}$

3C-Based Chromatin Interaction Analyses 1641

\section{PROTOCOLS}

1 Formaldehyde Cross-Linking

2 Preparation of Cross-Linked Chromatin for ChIP 
4 ChIP-Quantitative PCR (ChIP-qPCR)

7 Generation of 3C Libraries from Cross-Linked Cells

10 PCR Detection of 3C Ligation Products Present in 3C, ChIP-loop, and Control Libraries: Library Titration and Interaction Frequency Analysis

\section{INFORMATION PANELS}

Formaldehyde

\section{CHAPTER 21}

\section{Mapping of In Vivo RNA-Binding Sites by UV-Cross-Linking} Immunoprecipitation (CLIP)

Jennifer C. Darnell, Aldo Mele, Ka Ying Sharon Hung, and Robert B. Darnell

\section{INTRODUCTION}

The Cross-Linking Immunoprecipitation Method 1706

$\begin{array}{lr}\text { High-Throughput Sequencing (HITS) CLIP } & 1708\end{array}$

$\begin{array}{lr}\text { Validation of CLIP Results } & 1708\end{array}$

$\begin{array}{lr}\text { CLIP Method Variations } & 1709\end{array}$

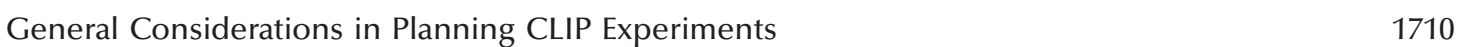

\section{PROTOCOLS}

1 Optimization of Immunoprecipitation Stringency for CLIP 1713

2 UV Cross-Linking of Live Cells and Lysate Preparation $\quad 1720$

3 RNase Titration, Immunoprecipitation, and SDS-PAGE 1724

4 3'-Linker Ligation and Size Selection by SDS-PAGE 1734

- Alternative Protocol: 5'-End Labeling of Dephosphorylated RL3 Linker 1738

5 Isolation of the RNA Tags, 5'-Linker Ligation, and Reverse Transcription PCR Amplification 1741

6 Sequencing of RNA CLIP Tags 1751

7 Gel Purification and Storage of RNA Linkers 1753

\section{INFORMATION PANELS}

Mechanism and Specificity of UV-Protein Cross-Linking 1756

$\begin{array}{lr}\text { HITS-CLIP Data Analysis } & 1758\end{array}$ 
xxii / Contents

\section{CHAPTER 22}

Gateway-Compatible Yeast One-Hybrid and Two-Hybrid Assays

John S. Reece-Hoyes and Albertha J.M. Walhout

\section{INTRODUCTION}

The Yeast Two-Hybrid (Y2H) System: Concept and Methodology

The Yeast One-Hybrid (Y1H) System: Concept and Methodology 1767

Y2H and Y1H Assays: Advantages and Disadvantages 1768

$\begin{array}{lr}\text { False Positives } & 1769\end{array}$

$\begin{array}{lr}\text { Protocols for Yeast One-Hybrid and Two-Hybrid Systems } & 1770\end{array}$

\section{PROTOCOLS}

1 Generating Yeast One-Hybrid DNA-Bait Strains 1773

- Alternative Protocol: Creating Entry Clones from DNA-Baits Generated by Annealing Primers

2 Generating Yeast Two-Hybrid Bait Strains

3 Identifying Interactors from an Activation Domain Prey Library

1792

High-Efficiency Yeast Transformation

5 Colony Lift Colorimetric Assay for $\beta$-Galactosidase Activity 1803

6 Yeast Colony PCR 1805

\section{INFORMATION PANELS}

$\begin{array}{lr}\text { Why Integrate DNA-Baits? } & 1808\end{array}$

$\begin{array}{lr}\text { Choosing a Vector and a Yeast Strain } & 1809\end{array}$

Replica-Plating and Replica-Cleaning Using Velvets 1810

\section{APPENDICES}

\section{APPENDIX 1}

Tris Buffers 


\section{APPENDIX 2}

PREPARATION OF GLASSWARE AND PLASTICWARE

Decontamination of Concentrated Solutions of Ethidium Bromide (Solutions

Decontamination of Dilute Solutions of Ethidium Bromide (e.g., Electrophoresis Buffer

\section{APPENDIX 3}


xxiv / Contents

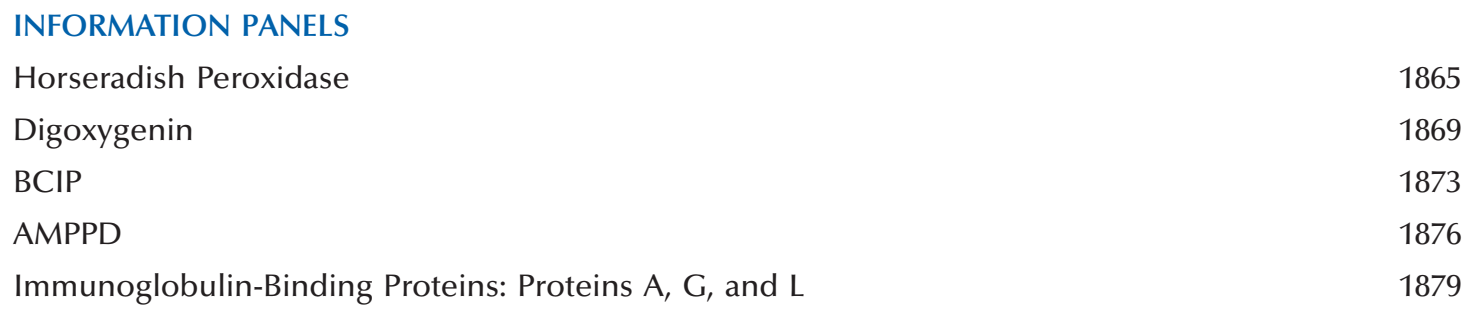




\section{List of Tables}

\section{CHAPTER 1}

Isolation and Quantification of DNA

Cations commonly used in ethanol precipitation of DNA 22

Carriers used in ethanol precipitation $\quad 23$

$\begin{array}{lr}\text { Nucleotide cutoffs for Microcon concentrators } & 28\end{array}$

Table strains of Escherichia coli commonly used as hosts for bacteriophage M13 35

Proteolytic enzymes $\quad 44$

$\begin{array}{lr}\text { SNET lysis buffer volumes } & 59\end{array}$

\section{CHAPTER 2}

Analysis of DNA

Properties of different types of agaroses $\quad 84$

Range of separation of DNA fragments through different types of agaroses 84

Properties of membranes used for Southern blotting and hybridization 92

Range of separation in gels containing different amounts of standard

low-EEO agarose $\quad 96$

Effective range of separation of DNAs in polyacrylamide gels $\quad 106$

$\begin{array}{ll}\text { Volumes of reagents used to cast polyacrylamide gels } & 107\end{array}$

Sensitivity of autoradiographic methods for detection of radioisotopes 124

Fixing DNA to the membrane for hybridization 137

$\begin{array}{lr}\text { Background-How to avoid it } & 149\end{array}$

\section{CHAPTER 3}

Cloning and Transformation with Plasmid Vectors

$\begin{array}{ll}\text { Commercial kits for transformation of Escherichia coli } & 161\end{array}$

Conditions for dephosphorylation of 5' residues from DNA 190

$\begin{array}{ll}\text { Components for top agar } & 211\end{array}$

E. coli-A timeline $\quad 214$

$\begin{array}{lr}\text { Standard methods for cloning amplified DNA } & 219\end{array}$

$\begin{array}{ll}\text { Properties of the Gateway-modified att sites } & 220\end{array}$

Ligase-free methods $\quad 223$

DNA ligases $\quad 236$

Summary: Major classes of restriction enzymes $\quad 242$

$\begin{array}{ll}\text { Plasmid replicons and modes of replication } & 251\end{array}$

Control elements that regulate replication $\quad 252$

Toxic genes used in positive-selection systems 255 


\section{CHAPTER 4}

Gateway Recombinational Cloning

Advantages and disadvantages of different recombination-based cloning methods

\section{CHAPTER 5}

Working with Bacterial Artificial Chromosomes and Other High-Capacity Vectors

High-capacity vectors for genomic cloning

Primers required for selecting cointegrates

\section{CHAPTER 6}

Extraction, Purification, and Analysis of RNA from Eukaryotic Cells

Commercially available monophasic lysis reagents

Number of larvae and adult worms required for total RNA extraction

Overview of spectrophotometric and fluorescent-based dye methods

Salt solutions for precipitating RNA

Commercially available oligo(dT)-magnetic beads

Properties of nylon membranes used for immobilization of DNA and RNA

Percentage of acrylamide for effective separation of RNAs

Recipes for $8 \mathrm{M}$ urea denaturing acrylamide gels

Expected mobilities of tracking dyes when run with RNA

Sequence of staining RNA and fixing to the membrane

Background in Southern and northern hybridizations and how to avoid it

Percentage of gel for purifying various DNA fragments

Expected mobilities of tracking dyes (DNA)

Volumes of polyacrylamide required to cast minigels of various percentages

Promoter sequences recognized by bacteriophage-encoded RNA polymerases

\section{CHAPTER 7}

\section{Polymerase Chain Reaction}

Primer design

Detecting, analyzing, and quantifying mRNAs

Enhancers commonly used to improve the efficiency of amplification

of GC-rich templates

Thermostable DNA polymerases: Properties

Thermostable DNA polymerases: Applications

Examples of commercial kits for one-step reverse transcription PCR

Conditions for standard PCRs catalyzed by Taq DNA polymerase

\section{CHAPTER 8}

\section{Bioinformatics}

Summary of several BLAST variants

List of other primer design tools

\section{CHAPTER 9}

Quantitation of DNA and RNA by Real-Time Polymerase Chain Reaction 
Commonly used reporter-quencher pairs for TaqMan probes

Commonly used reporter-quencher pairs for molecular beacon probes

Commonly used reporter-quencher pairs for Scorpion probes

\section{CHAPTER 10}

\section{Nucleic Acid Platform Technologies}

T7 linear amplification of DNA (TLAD) of small DNA molecules

Second-strand synthesis with limiting primer amounts

\section{CHAPTER 11}

DNA Sequencing

Comparison of various next-generation sequencing platforms

Sequences of adaptors and primers

Volumes of diluted DNA ladder and of AMPure beads for each beads:DNA ratio

Optimum ratios of the DNA concentration in the low-molecular-weight peaks to the 900 -bp peak

\section{CHAPTER 12}

Analysis of DNA Methylation in Mammalian Cells

Overview of methods for DNA methylation analysis

Commercial kits for bisulfite conversion of DNA

Commercial kits to aid with MS-PCR

Commercial kits for immunoprecipitation-based detection of DNA methylation

Programs for the identification of CpG islands

Programs for the design of primers for multiple genomic loci

Summary of data and statistical analysis methods used by different genome-wide high-throughput deep-sequencing DNA methylation studies

\section{CHAPTER 13}

Preparation of Labeled DNA, RNA, and Oligonucleotide Probes

Methods used to label nucleic acids in vitro

Inosine-containing codons recommended for use in

oligonucleotide probes

End-labeling of DNA

Percent polyacrylamide required to resolve oligonucleotides

The domains of $E$. coli DNA polymerase I

Promoter sequences recognized by bacteriophage-encoded RNA polymerases

\section{CHAPTER 14}

Methods for In Vitro Mutagenesis 
Primers used for the cloning of DNA Pol $\beta$, Pol $\eta$, and Pol ı cDNAs and for the construction of random mutagenesis libraries

\section{CHAPTER 15}

Introducing Genes into Cultured Mammalian Cells

Transfection methods

Commercial kits and reagents for transfection

Dimensions of dishes used for cell culture

Recommendations for electroporation using the Bio-Rad ShockPod 1176

Selective G418 concentration ranges

Selective concentrations of Hygromycin B

Selective concentrations of Blasticidin S

\section{CHAPTER 16}

Introducing Genes into Mammalian Cells: Viral Vectors

Examples of helper cell lines that support the growth of adenovirus E1 mutants

Regions of the viral genome that regulate DNA synthesis and transcription are clustered in the two LTRs that consist of three functional regions

Comparison of major characteristics of four commonly used RNA and DNA viral vectors

Choices of backbones for molecular clones of adenovirus vectors

Target tissue-specific AAV capsid selection

Amino acid sequence of epitope tags

\section{CHAPTER 17}

Analysis of Gene Regulation Using Reporter Systems

Comparison of commonly used reporter genes

Common enhancers used in the chemiluminescent detection of

$\beta$-galactosidase activity

Properties of selected monomeric fluorescent proteins

Properties of selected dimeric and tetramic fluorescent proteins

Protease cleavage sites commonly used for epitope tag removal

\section{CHAPTER 18}

RNA Interference and Small RNA Analysis

dsRNA and siRNA design tools

Volumes of cells, DharmaFECT 4, and siRNAs (or ASOs) used for transfection of cultured mammalian cells

Volumes of cells, DharmaFECT 4, and dsRNA (siRNAs or ASOs) used for transfection of cultured Drosophila cells

List of human and mouse shRNA/siRNA libraries available for genome-wide RNAi screens 


\section{CHAPTER 19}

Expressing Cloned Genes for Protein Production, Purification, and Analysis

Comparison of hosts for recombinant protein production

Common vectors for protein expression

Common fusion proteins used for recombinant protein purification

Common endopeptidases used for cleavage of recombinant fusion proteins

Effective range of separation of SDS-polyacrylamide gels

Solutions for preparing resolving gels for Tris-glycine SDS-PAGE

Solutions for preparing 5\% stacking gels for Tris-glycine SDS-PAGE

Buffers for transfer of proteins from polyacrylamide gels to membranes

Chromogenic and chemiluminescent methods of detection of immobilized antigens

Physical properties of detergents commonly used in membrane protein purification

\section{CHAPTER 20}

Cross-Linking Technologies for Analysis of Chromatin Structure and Function

Overview of the ChIP-based methods

Overview of the features of 3C-based methods

\section{CHAPTER 21}

Mapping of In Vivo RNA-Binding Sites by UV-Cross-Linking Immunoprecipitation (CLIP)

Representative RNA-binding proteins studied by CLIP

Variant CLIP protocols

\section{CHAPTER 22}

Gateway-Compatible Yeast One-Hybrid and Two-Hybrid Assays

Y2H DB-bait selection

$\mathrm{Y} 2 \mathrm{H}$ AD-prey selection

Y1H DNA-bait selection

Y1H AD-prey selection

Advantages and disadvantages of $\mathrm{Y} 2 \mathrm{H}$ and $\mathrm{Y} 1 \mathrm{H}$ assays

Strains and markers used in $\mathrm{Y} 1 \mathrm{H}$ and $\mathrm{Y} 2 \mathrm{H}$ assays

List of vectors and related primers

Evaluating $\mathrm{Y} 1 \mathrm{H} / \mathrm{Y} 2 \mathrm{H}$ interactions

\section{APPENDIX 1}

Reagents and Buffers Used in Molecular Cloning

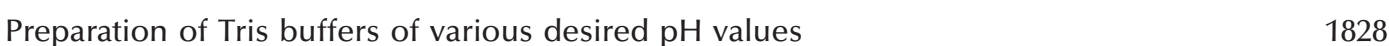

$\begin{array}{ll}\text { Properties of good buffers } & 1830\end{array}$

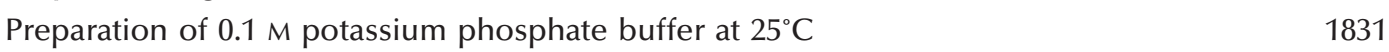

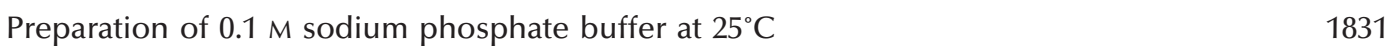

Concentrations of acids and bases: common commercial strengths 1833

Approximate $\mathrm{pH}$ values for various concentrations of stock solutions 1833

$\begin{array}{ll}\text { Commonly used antibiotic solutions } & 1835\end{array}$

$\begin{array}{lr}\text { Antibiotic modes of action } & 1835\end{array}$ 
XXX / List of Tables

\section{APPENDIX 3}

Detection Systems

Chemiluminescent assays for immunoassay and nucleic acid hybridization labels

Applications of chemiluminescence in molecular biology

Binding of protein $\mathrm{A}$ and protein $\mathrm{G}$ to the Fc region of

mammalian immunoglobulins

Binding of immunoglobulins to protein L, protein A, and protein G 


\section{Preface}

$\mathrm{T}$

HE READY AVAILABILITY OF THE COMPLETE GENOME SEQUENCES for humans and model organisms has profoundly affected the way in which biologists of every discipline now practice science. Exploration of the vast genomic landscape required the development of a great variety of new experimental techniques and approaches. Inevitably, venerable cloning manuals became outdated and established methods were rendered obsolete. These events provided the major impetus for a thorough revision of Molecular Cloning.

In the first stages of Molecular Cloning 4 (MC4), we undertook an extensive review process to determine what old material should be kept, what new material should be added, and, most difficult of all, what material should be deleted. The names of the many scientists who contributed invaluable advice during the review process are listed on the following acknowledgments page. We are grateful to them all.

It is of course impossible to include in any single laboratory manual all experimental methods used in molecular biology, and so choices, sometimes tough ones, had to be made. Individuals may disagree with some of our choices (and we suspect some will). However, our two guiding principles are as follows. First, Molecular Cloning is a "nucleic acid-centric" laboratory manual, and therefore in general we have not included methods that do not directly involve DNA or RNA. So, although MC4 contains a chapter on yeast two-hybrid procedures for analyzing protein-protein interactions, we did not include the many other approaches for studying protein-protein interactions that do not directly involve nucleic acids. Second, we have attempted to include as many as possible of those nucleic acid-based methods that are widely used in molecular and cellular biology laboratories with the hope in the John Lockean sense that we "do the greatest good for the most people." The harder task for us was to decide which material to delete. However, our task was made somewhat easier by the agreement of our publisher, Cold Spring Harbor Laboratory Press, to make these older methods freely available on the Cold Spring Harbor Protocols website (www.cshprotocols.org).

The explosion of new experimental approaches has made it impractical, if not impossible, for any single person (or even two) to write with authority on all the relevant experimental methods. As a result, a major departure from previous editions of Molecular Cloning was the commissioning of experts in the field to write specific chapters and to contribute specific protocols. Without the enthusiastic participation of these scientists, MC4 simply would not exist.

Since the last edition of Molecular Cloning, there has been a relentless and continuing proliferation of commercial "kits," which is both a blessing and a curse. On the one hand, kits offer tremendous convenience, particularly for procedures that are not routinely used in an individual laboratory. On the other hand, kits can often be too convenient, enabling users to perform procedures without understanding the underlying principles of the method. Where possible, we have attempted to deal with this dilemma by providing lists of commercially available kits and also describing how they work.

There are many people who played essential roles in the production of MC4 and whom we gratefully acknowledge. Ann Boyle was instrumental in getting MC4 off the ground and played a critical organizational role during the early stages of the project. Subsequently, her responsibilities were taken over by the able assistance of Alex Gann. Sara Deibler contributed at all stages of 
MC4 in many ways, but in particular in assisting with writing, editing, and proofreading. Monica Salani made substantial contributions to the content and writing of Chapter 9.

We are especially grateful for the enthusiastic support, extraordinary cooperation, and tolerance of the staff of the Cold Spring Harbor Laboratory Press - in particular Jan Argentine, who managed the entire project and kept a close eye on its finances; Maryliz Dickerson, our project manager; our developmental editors Kaaren Janssen, Judy Cuddihy, and Michael Zierler; Denise Weiss, the Production Manager; our production editor, Kathleen Bubbeo; and, of course, John Inglis, the éminence grise of Cold Spring Harbor Laboratory Press.

MiCHAEL R. GREEN

JOSEPH SAMBROOK

\section{A Note from the Publisher}

Readers are encouraged to visit the website www.molecularcloning.org to obtain up-to-date information about all aspects of this book and its contents. 


\section{Acknowledgments}

The authors wish to thank the following colleagues for their valuable assistance:

H. Efsun Arda

Michael F. Carey

Darryl Conte

Job Dekker

Claude Gazin

Paul Kaufman

Nathan Lawson
Chengjian Li
Ling Lin
Donald Rio
Sarah Sheppard
Stephen Smale

The Publisher wishes to thank the following:

Paula Bubulya

Tom Bubulya
Nicole Nichols

Sathees Raghavan
Narendra Wajapeyee

Marian Walhout

Phillip Zamore

Maria Zapp

Barton Slatko 


\section{General Safety and Hazardous Material Information}

This manual should be used by laboratory personnel with experience in laboratory and chemical safety or students under the supervision of suitably trained personnel. The procedures, chemicals, and equipment referenced in this manual are hazardous and can cause serious injury unless performed, handled, and used with care and in a manner consistent with safe laboratory practices. Students and researchers using the procedures in this manual do so at their own risk. It is essential for your safety that you consult the appropriate Material Safety Data Sheets, the manufacturers' manuals accompanying equipment, and your institution's Environmental Health and Safety Office, as well as the General Safety and Disposal Information in Appendix 4 for proper handling of hazardous materials described in this manual. Cold Spring Harbor Laboratory makes no representations or warranties with respect to the material set forth in this manual and has no liability in connection with the use of these materials.

All registered trademarks, trade names, and brand names mentioned in this book are the property of the respective owners. Readers should consult individual manufacturers and other resources for current and specific product information. Appropriate sources for obtaining safety information and general guidelines for laboratory safety are provided in the General Safety and Hazardous Material appendix of this manual. 